\title{
Stress Distribution in Soils under Pile Cap of Tapered Piles in Compressible Clay
}

\author{
T.W. Adejumo ${ }^{1}$ \\ ${ }^{I}$ Department of Geotechnics and Environmental Engineering, Faculty of Civil Engineering, Belarusian National \\ Technical University, Minsk, Belarus.
}

\begin{abstract}
This research paper presents the results of comprehensive investigations on stress distribution in soils under pile cap of tapered piles in compressible clay. Compressible clay from Urucha and Shabani, area of Minsk province, Belarus was investigated in this work. The former was used for laboratory investigation, while field tests were conducted on the latter respectively. The results show the influence of axial compressive load on the magnitude, pattern and orientation of stresses in soils under the pile cap of loaded modeled instrumental piles bored into compressive clay soil. Stresses in the soils at different depths under the pile cap with reference to pile center lines were measured and compared with those obtained using Boussinesq's theory. Measured stresses are slightly higher than those calculated using the theory. The investigations also showed that, for tapered piles bored in compressive clay, the stress increases towards the center line of pile-pile cap joint irrespective of tapering angle only up to $0.5 \mathrm{~m}$ below the cap, (model), beyond this point, the magnitude and pattern of stress changes. The vertical normal stress under the pile cap increases from zero at the surface to $42 \%$ in depth lower than $3.5 R$, and $55 \%$ beyond this point. The maximum principal stress is directed along the radius vector $R$ and reduces radially outward from the pile centerline. The normal and shear stress vectors are less in pile with higher center to center spacing. In addition, stress distribution under pile cap is also a function of pile spacing and tapering angle. Clearly striated stressed zones of deformation under loaded pile cap, having depth in multiples of pile diameter were observed.
\end{abstract}

Keywords: - Compressible clay, Deformation, Settlement, Stress in soil, Tapered pile

\section{INTRODUCTION}

As foundation engineers, a significant amount of the work we do is based on the concept of stress. Stress analysis allows us to obtain the normal and shear stresses in any plane passing through a point, given the normal and shear stresses acting on mutually perpendicular planes passing through the point [1]. When pile is penetrates in a downward frictional mode, a failure zone is developed along the soil-pile interface which partly upheaves laterally and disturbs the soil below the pile tip. Partly consolidation develops around soil-pile interface when soil compresses elastically below the critical depth [2].

The pile cap is defined as a structural member used to distribute the load to the piles [3]. The flexibility of the pile cap affects individual pile head forces significantly and affects the bending moments and shear forces in individual piles as well, even though the displacement of the pile cap does not vary much [4]. When the pile cap distributes an equal magnitude of load on each pile, the following assumption must be satisfied according to Bowles; (a) the pile cap is in contact with the ground, (b) the piles are all vertical, (c) a load is applied at center of pile group, and (d) the pile group is symmetrical [3].

Investigations and data on measured stress in clay are limited, and even the available few are mostly for compacted clays. There is almost no convenient way of inserting a load cell into natural (undisturbed) clay without causing severe stress redistribution problems. A variety of laboratory tests as well as field techniques are available, each having its own limitations as well as advantages [5]. Equations for the stresses and strains induced in a homogeneous, isotropic, weightless, linearly elastic half space, with a plane horizontal surface, by a point load perpendicular to the surface and acting at the surface, was first solved in usable form by Boussinesq [6] \& [7], and later by Acum and Fox [8], with a few others in between. Foster and Fergus obtained information on the spatial variation in developed pressure in compacted clay. They concluded that Boussinesq's theory is adequately accurate, at least for compacted clays [9]. Solutions for the stress and deformation caused by a vertical point load applied at the surface have been presented by Koning [10] and Barber [11]. Biot established an equation for determination of normal stress in rigid floor [12]. Cummings worked further on Biot's equations to determine the vertical normal stress on the base directly beneath the center of a uniformly loaded disc [13]. The lateral deformation of piles decreases with increase in distance from the pile center line, while outward radial deformations recorded around the pile decreases downwards along the length [14]. The skin friction and radial stress are highly influenced by tapered piles compared with conventional piles. The tapering and wedging 
effects are responsible for increase in normalized skin friction and normalized lateral stresses. Taper-shaped piles offer a larger resistance than the cylindrical piles [2] and [15].

Although the assumptions are usually made that the soil is homogeneous and isotropic, it is apparent that most field problems involve soils that are stratified and anisotropic [16]. Based on the strength of their digenetic bonds, clay and clay-shale have been grouped into 3: 1) over consolidated plastic clay with weak or no bond; 2) over consolidated plastic clay with well-developed digenetic bonds and c) over consolidated plastic clay with strongly-developed digenetic bonds [17]. Clay soils around Minsk region falls into the third category [18]-[20]. In spite of these results however, more work still needed to be done for greater understanding of the dynamics of pile-soil or pile cap-soil behavior under stress.

The object of this paper therefore, is to present the results of a series of modeled pile tests on stress distribution under the pile cap of tapered piles conducted in the research laboratory, Geotechnical and Environmental Engineering department, Belarusian National Technical University, Minsk, and field tests on the outskirt of Minsk province, Belarus. This investigation is essential in the understanding of structural behavior of the soil under axially loaded pile cap of tapered piles, and its response to loading. Obtaining the stress distribution of soil immediately the below the piles cap under loads is a key factor to understanding its behavior and response to deformation and utmost functionality. The foregoing therefore, explains the relevance of this investigation.

\section{MATERIALS AND METHOD}

The materials and method employed in this work can simply be divided into; a) theoretical determination of the stress exerted on the soil using Boussinesq equation, b) laboratory investigations for the model tapered piles, c) field tests with bored tapered piles having pile cap in contact with the soil, and d) analysis of both calculated and measured stress from the controlled tests.

\subsection{Theoretical Determination of Stress}

Besides the tabulation of Ahlvin and Uleri [21], increase in vertical stress at any point below a rectangular area subjected to uniform load can be calculated using Boussinesq's solution [22], [16]. For most practical analyses of the settlement behavior of soils, it is assumed that the volume of the soil is controlled exclusively by the vertical stress, $\sigma_{z}$. Using Boussinesq solution and r-t-z coordinate system, superimposed on the traditional $x-y$ coordinates, the vertical stress in soil under the axially loaded pile cap in Fig. 1 is given by:

$$
\sigma_{z}=\frac{3 P}{2 \pi} \frac{Z^{\mathrm{a}}}{R^{5}}=\frac{3 P}{2 \pi R^{2}} \cos ^{\mathrm{a}} \beta=I \frac{P}{Z^{2}}
$$

Where $\mathrm{P}$ is axial load; I is influence factor (ratio of $\mathrm{r} / \mathrm{z}$ ) given by Terzaghi [23] and Taylor [24];

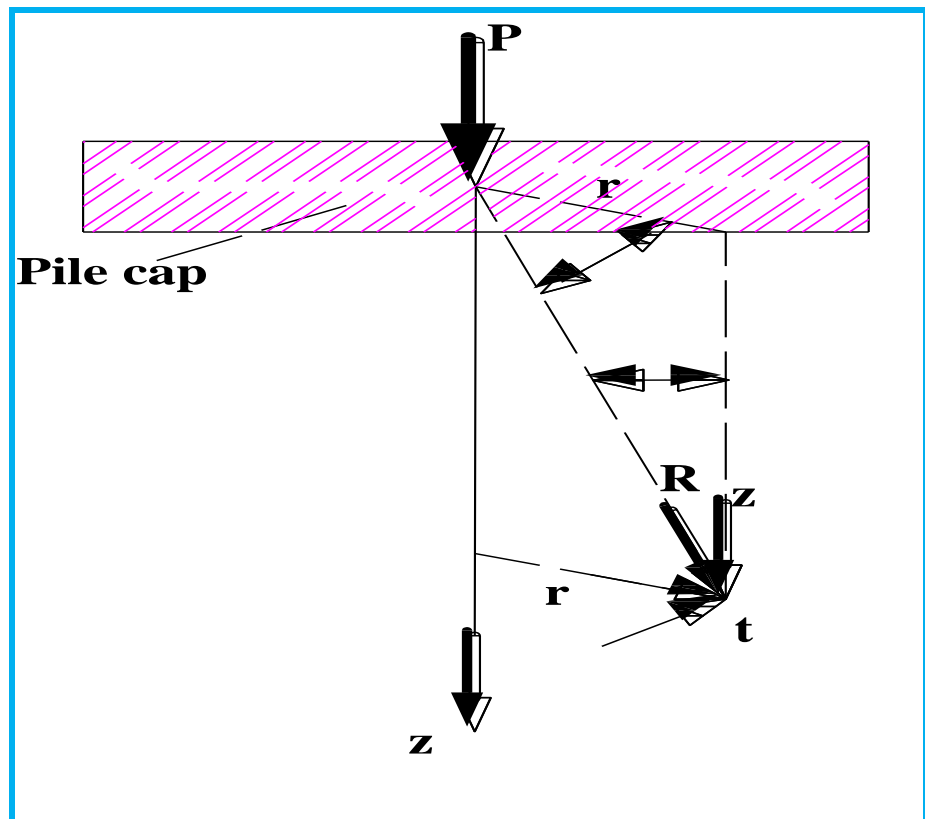

Fig. 1: Symbols and direction of entities used in the equation for stress under axially loaded pile cap

Introducing $\mathrm{x}$-axis in disperses and Poisson's ratio, the spatial distribution of normal stress and shearing stress is given by the equations: 


$$
\begin{aligned}
& \sigma_{x}=\frac{P}{2 \pi}\left[3 \frac{x^{2} z}{R^{5}}-(1-2 v)\left(\frac{x^{2}-y^{2}}{R r^{2}(R+z)}+\frac{y^{2} z}{R^{3} r^{2}}\right)\right] \\
& \sigma_{y}=\frac{P}{2 \pi}\left[3 \frac{y^{2} z}{R^{5}}-(1-2 v)\left(\frac{y^{2}-x^{2}}{R r^{2}(R+z)}+\frac{x^{2} z}{R^{2} r^{2}}\right)\right] \\
& \sigma_{y}=\frac{P}{2 \pi}\left[3 \frac{r^{2} z}{R^{5}}-(1-2 v) \frac{R-z}{R r^{2}}\right] \\
& \sigma_{t}=\frac{P}{2 \pi}\left[(1-2 v)\left(\frac{1}{r^{2}}-\frac{z}{R^{2}}-\frac{z}{R^{2}}\right)\right] \\
& \tau_{r z}=\frac{3 P}{2 \pi} \frac{r z^{2}}{R^{5}} \\
& \tau_{z x}=\frac{3 P}{2 \pi} \frac{z^{2} x}{R^{5}} \\
& \tau_{z y}=\frac{3 P}{2 \pi} \frac{z^{2} y}{R^{5}} \\
& \tau_{r t}=\tau_{t v}=0
\end{aligned}
$$

\subsection{Laboratory Investigations}

Clay samples tested were taken from a construction site at Urucha, at the outskirt of Minsk, Belarus. The soil was conditioned and detailed laboratory investigation was carried out to determine the stress distribution under the pile cap when modeled tapered piles were bored into it. The test with modeled piles of $20 \mathrm{~mm}$ diameter and $200 \mathrm{~mm}$ long was conducted in the test tank shown in Fig. 2, in the post graduate laboratory of the Department of Geotechnics \& Civil Engineering, Faculty of Civil Engineering, Belarusian National University, Minsk, Belarus. A detailed, easy-to-follow procedure on this has been covered in my earlier works; Adejumo et al [25] and Adejumo [26]. Test results were collected and collated for further analysis.

\subsection{Field Investigations}

The field tests were performed on 4 No $320 \mathrm{~mm}$ diameter tapered piles with tapering angles $(\alpha)$ of $1.43^{\circ}$ and 0.950 , and group efficiency of 0.85 and 0.95 at two test points respectively, at a construction site in Shabani industrial layout, on the outskirt of Minsk. The pile cap configuration is 2260 X 2260 X 500mm in dimension. Static loads were applied and maintained using a hydraulic jack (of 200T capacity) and were measured with a load cell as shown in Fig. 3. Reaction to the jack load is provided by a steel frame that is attached to an array of steel H-piles located at least $1.5 \mathrm{~m}$ away from the test piles. Pile cap settlements were measured relative to a fixed reference beam using 2 dial gauges. Displacement/settlement of soils around the piles measurements were made in reference to the pile cap using 5 dial gauges, Fig. 4 . The settlements were recorded for each loading increment at an interval of 15 minutes or the time when the movement of the indicator on the dial gauges becomes insignificant. The modeled test piles were instrumented with strain gauges connected to the stylishly perforated steel cone-heads by string-pulley (for static resistance) with censors to the pile centerline. The steel cone-heads with series of springs connected to the indicators were installed in the soils around the piles at depths $0.2 \mathrm{~m}, 0.5 \mathrm{~m}, 1.0 \mathrm{~m} 1.5 \mathrm{~m}$, and the 5 th one at $0.2 \mathrm{~m}$ outside the pile cap. The piles were subjected to axial compressive loads until the allowable pile settlement of $0.1 \mathrm{~d}$ (10\% of pile diameter) is reached or exceeded in line with the submission of [27-29]. The vertical normal stress and deformation during loading and unloading were then recorded. 


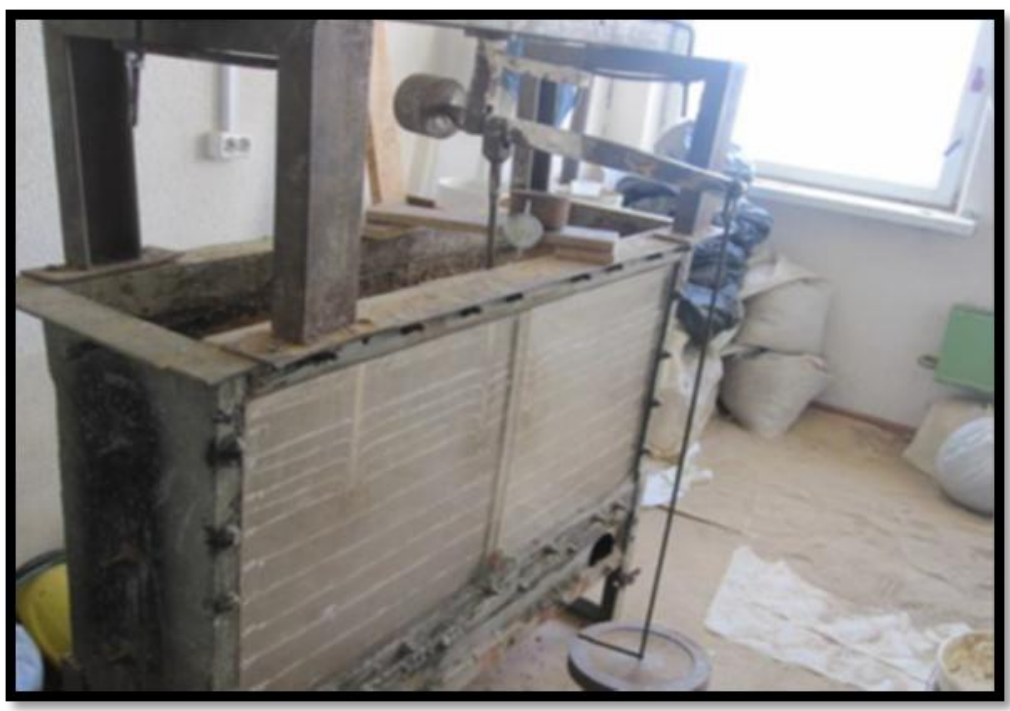

Fig. 2: Testing tank for laboratory investigations

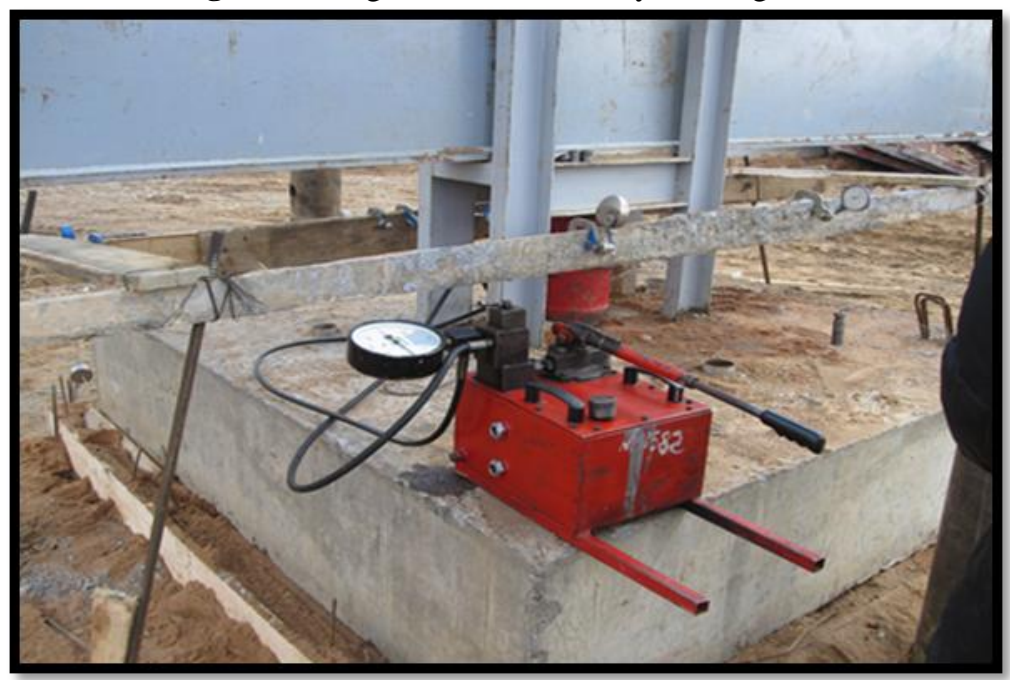

Fig. 3: Loading device for field investigations (200Tonnes capacity)

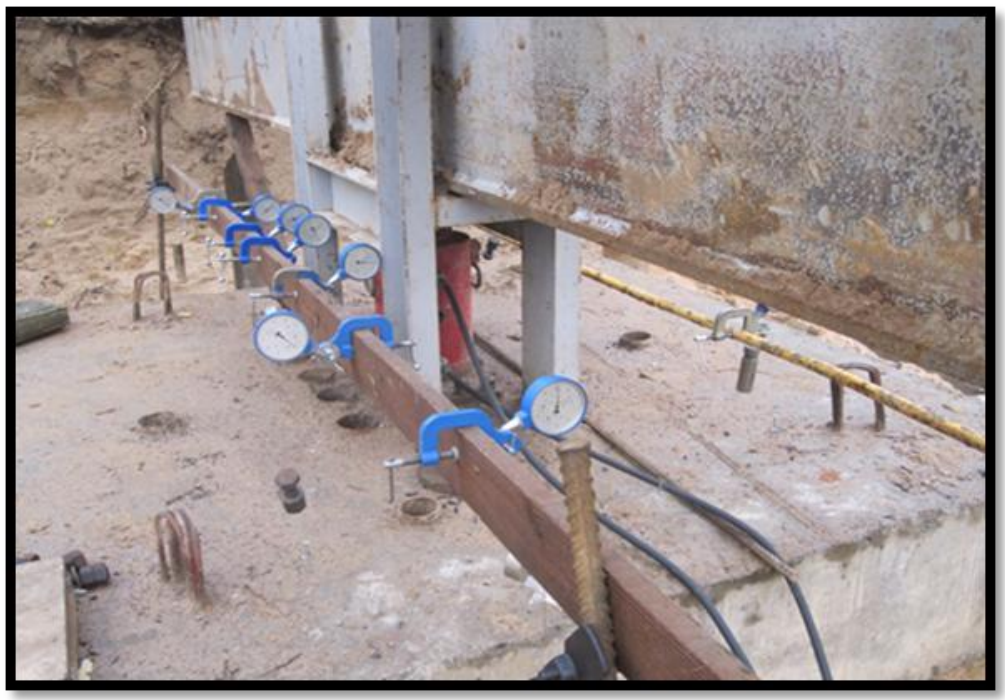

Fig. 4: Dial guages for sensor movement measurement under pile cap 


\section{RESULTS AND DISCUSSION}

The results of geotechnical properties of the compressive clay investigated in the laboratory is presented in Table1 below. It shows a high void ration (e) and cohesion with maximum values of 1.92 and 30 $\mathrm{kPa}$ respectively, which indicated the compressibility of the sample. It does not drain readily and may absorb water by capillary action, which lead to loss of strength.

Table 1: Summary of geotechnical properties of tested clay sample

\begin{tabular}{|c|c|c|}
\hline Parameters & Values for the Sample & \multirow{12}{*}{ 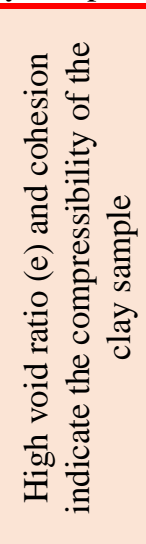 } \\
\hline Density $\gamma\left(\mathrm{kN} / \mathrm{m}^{3}\right)$ & 18 & \\
\hline Moisture content (w) & 10 & \\
\hline Specific gravity of solids & 2.63 & \\
\hline Liquid Limit (\%) & $23-29$ & \\
\hline Plastic Limit (\%) & $17-19$ & \\
\hline Plasticity index $(\%)$ & $5-10$ & \\
\hline Liquidity Index (\%) & $0.1-0.3$ & \\
\hline Void ratio $(\mathbf{e})$ & $0.70-1.92$ & \\
\hline Cohesion $(\mathrm{kPa})$ & $25-30$ & \\
\hline Angle of internal friction $\left(\varphi^{\circ}\right)$ & $7-18$ & \\
\hline $\begin{array}{l}\text { Modulus of Deformation } \mathbf{E} \\
\qquad(\mathrm{kPa})\end{array}$ & $7.5-13$ & \\
\hline
\end{tabular}

The result of theoretical (calculated) stress is shown in Table 2. Using the r-t-z coordinate system, with the normal stress equal to the radius vector $R$ at equilibrium, the maximum vertical shear stress beyond which the soil experiences yield is $7.03 \mathrm{kPa}$. Table 3 shows the normal and shear stress measured during loading and unloading. It shows slightly higher shear stress value of $7.39 \mathrm{kPa}$ for the corresponding load. The vector correlation coefficient of $r=0.922$ was obtained for the calculated and the experimental stress.

Table 2: Calculated (Theoretical) vertical normal and shear stress under pile cap

\begin{tabular}{|c|c|c|c|c|c|c|c|c|c|c|c|c|c|c|c|}
\hline $\begin{array}{c}\text { Load } \\
(\mathrm{MPa})\end{array}$ & \multicolumn{2}{|c|}{0.00} & \multicolumn{2}{c|}{0.50} & \multicolumn{2}{c|}{1.00} & \multicolumn{2}{c|}{1.50} & \multicolumn{2}{c|}{2.00} & \multicolumn{2}{c|}{2.50} & \multicolumn{2}{|c|}{3.00} \\
\hline $\begin{array}{c}\text { Stress } \\
(\mathrm{kPa})\end{array}$ & $\sigma$ & $\tau$ & $\sigma$ & $\tau$ & $\sigma$ & $\tau$ & $\sigma$ & $\tau$ & $\sigma$ & $\tau$ & $\sigma$ & $\tau$ & $\sigma$ & $\tau$ \\
\hline $\begin{array}{c}\text { Pile } \\
\text { cap }\end{array}$ & 0.00 & 0.00 & 0.09 & 6.47 & 0.19 & 6.55 & 0.29 & 6.67 & 0.37 & 6.67 & 0.49 & 6.78 & 0.59 & 6.86 \\
\hline $0.2 \mathrm{~m}$ & 0.00 & 0.00 & 0.09 & 6.45 & 0.19 & 6.56 & 0.29 & 6.66 & 0.38 & 6.68 & 0.50 & 6.88 & 0.60 & 6.89 \\
\hline $0.5 \mathrm{~m}$ & 0.00 & 0.00 & 0.09 & 6.47 & 0.20 & 6.58 & 0.29 & 6.67 & 0.36 & 6.67 & 0.49 & 6.88 & 0.59 & 6.86 \\
\hline $1.0 \mathrm{~m}$ & 0.00 & 0.00 & 0.10 & 6.48 & 0.21 & 6.59 & 0.30 & 6.68 & 0.39 & 6.77 & 0.51 & 6.89 & 0.62 & 6.99 \\
\hline $1.5 \mathrm{~m}$ & 0.00 & 0.00 & 0.11 & 6.49 & 0.22 & 6.60 & 0.34 & 6.72 & 0.41 & 6.79 & 0.54 & 6.92 & 0.65 & 7.03 \\
\hline
\end{tabular}

Table 3: Measured (Field) vertical normal and shear stress under pile cap

\begin{tabular}{|c|c|c|c|c|c|c|c|c|c|c|c|c|c|c|c|}
\hline $\begin{array}{c}\text { Load } \\
(\mathrm{MPa})\end{array}$ & \multicolumn{2}{|c|}{0.00} & \multicolumn{2}{c|}{0.50} & \multicolumn{2}{c|}{1.00} & \multicolumn{2}{c|}{1.50} & \multicolumn{2}{c|}{2.00} & \multicolumn{2}{|c|}{2.50} & \multicolumn{2}{|c|}{3.00} \\
\hline $\begin{array}{c}\text { Stress } \\
(\mathrm{kPa})\end{array}$ & $\sigma$ & $\tau$ & $\sigma$ & $\tau$ & $\sigma$ & $\tau$ & $\sigma$ & $\tau$ & $\sigma$ & $\tau$ & $\sigma$ & $\tau$ & $\sigma$ & $\tau$ \\
\hline $\begin{array}{c}\text { Pile } \\
\text { cap }\end{array}$ & 0.00 & 0.00 & 0.10 & 6.85 & 0.19 & 6.93 & 0.29 & 7.03 & 0.37 & 7.11 & 0.49 & 7.23 & 0.59 & 7.33 \\
\hline $0.2 \mathrm{~m}$ & 0.00 & 0.00 & 0.09 & 6.83 & 0.19 & 6.93 & 0.29 & 7.03 & 0.38 & 7.12 & 0.50 & 7.24 & 0.60 & 7.34 \\
\hline $0.5 \mathrm{~m}$ & 0.00 & 0.00 & 0.10 & 6.85 & 0.20 & 6.94 & 0.29 & 7.03 & 0.36 & 7.10 & 0.49 & 7.23 & 0.59 & 7.33 \\
\hline $1.0 \mathrm{~m}$ & 0.00 & 0.00 & 0.10 & 6.84 & 0.21 & 6.95 & 0.30 & 7.04 & 0.39 & 7.13 & 0.51 & 7.25 & 0.62 & 7.39 \\
\hline $1.5 \mathrm{~m}$ & 0.00 & 0.00 & 0.11 & 6.86 & 0.22 & 6.97 & 0.34 & 7.08 & 0.41 & 7.15 & 0.54 & 7.28 & 0.65 & 7.39 \\
\hline
\end{tabular}

The Load-settlement curves for the laboratory instrumented tapered piles are shown in Figs. 5 and 6. Soils around tapered piles with higher tapering angle $(\alpha)$ show less settlement (5-10\% lower) at the initial period of loading. However, they produced a generally higher settlement and deformations in soils closer to and around the pile tip with a depth of failure tip influence zone 10 times the pile diameter, while those with less tapering 
angle is 7.5 times their diameter. Pile cap settlement is $110 \%$ and $102 \%$ higher than soil settlements around tapered piles with tapering angles of $0.95^{\circ}$ and $1.43^{\circ}$ respectively.

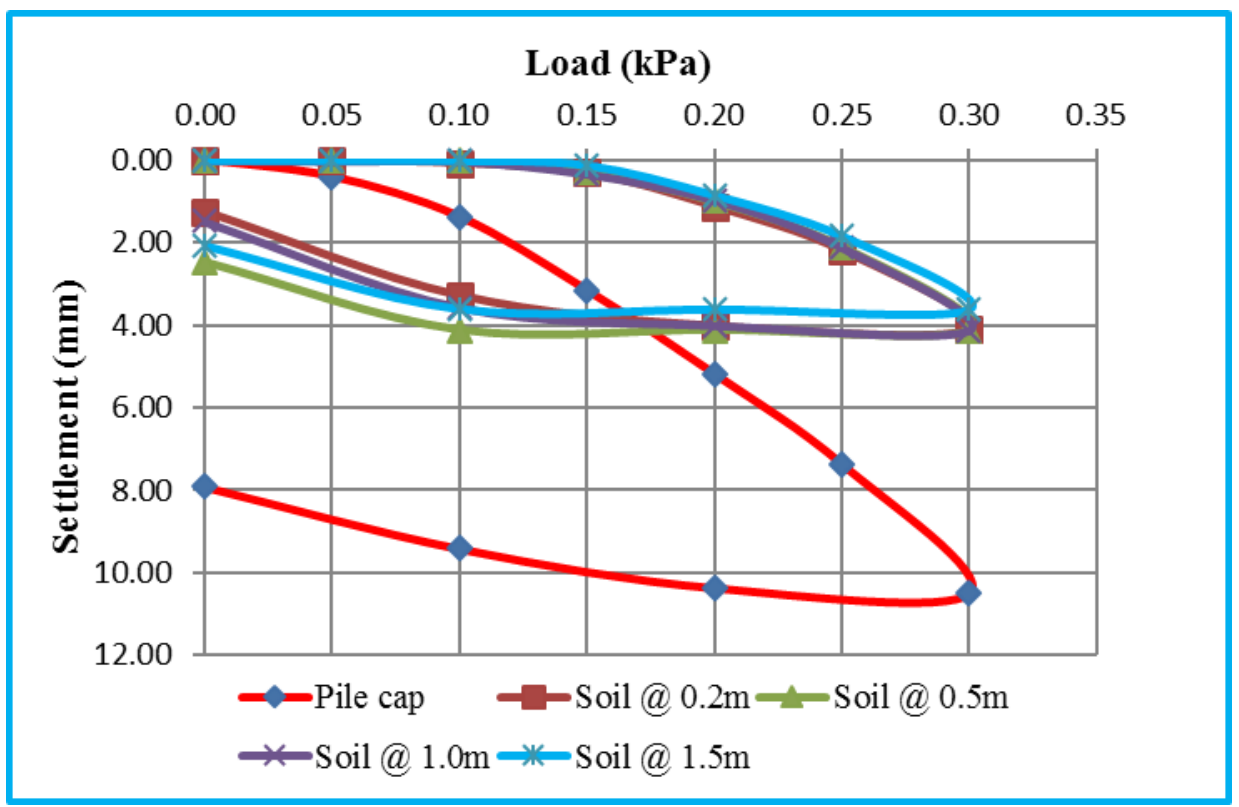

Fig. 5: Settlement of soils with $\alpha$ of $0.95^{\circ}$

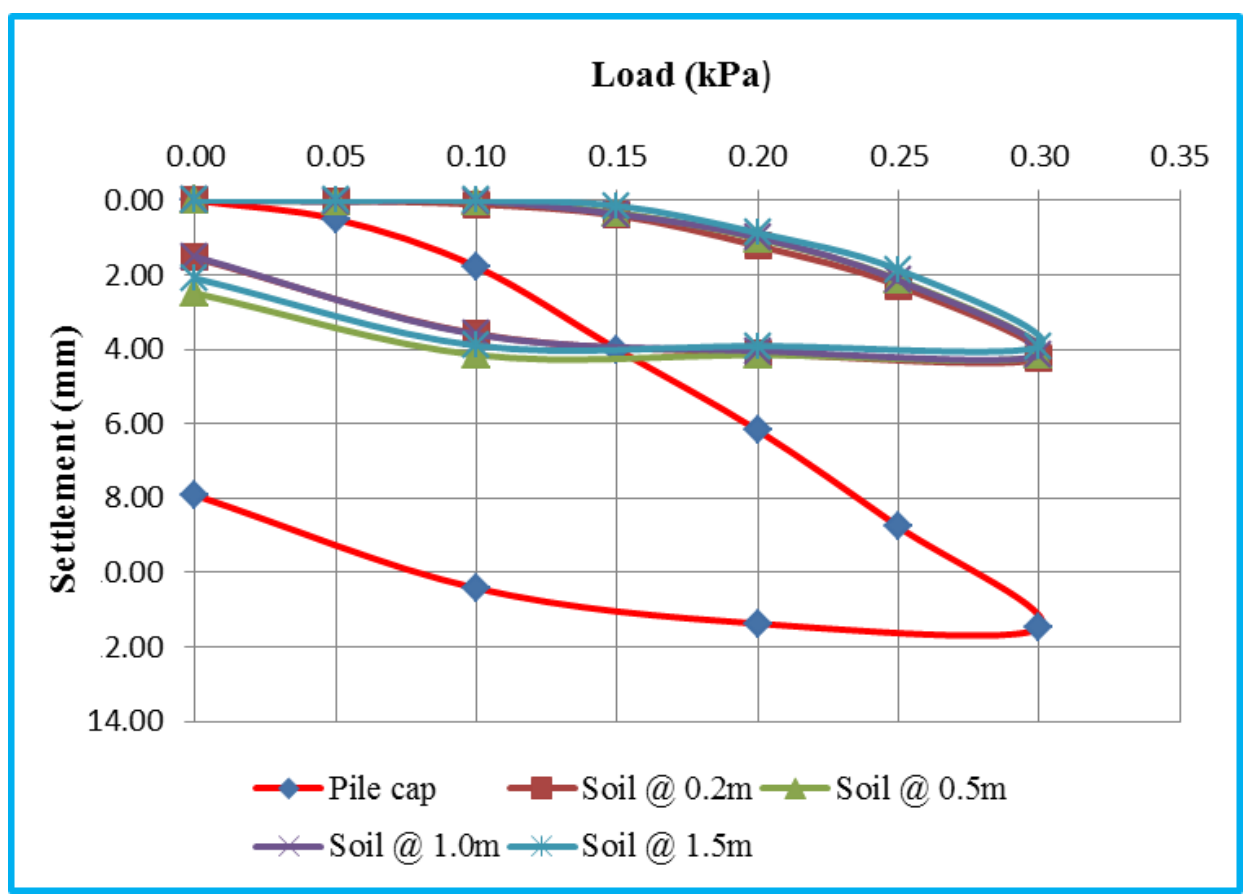

Fig. 6: Settlement of soils with $\alpha$ of $1.43^{\circ}$

Vertical and spatial stress along the pile axis under pile cap follow the usual pattern as shown in the failure bulb around an idealized pile of the four in a group of 4-piles in Fig. 7. It also followed the pattern of increasing radially outward from pile center in agreement with the finding of Salgado [30]. Four zones of deformation with depth of $2.5 \mathrm{D}, 3 \mathrm{D}, 2.5 \mathrm{D}$, and $2 \mathrm{D}$ from pile cap line downward. $\mathrm{D}$ is diameter of pile. 


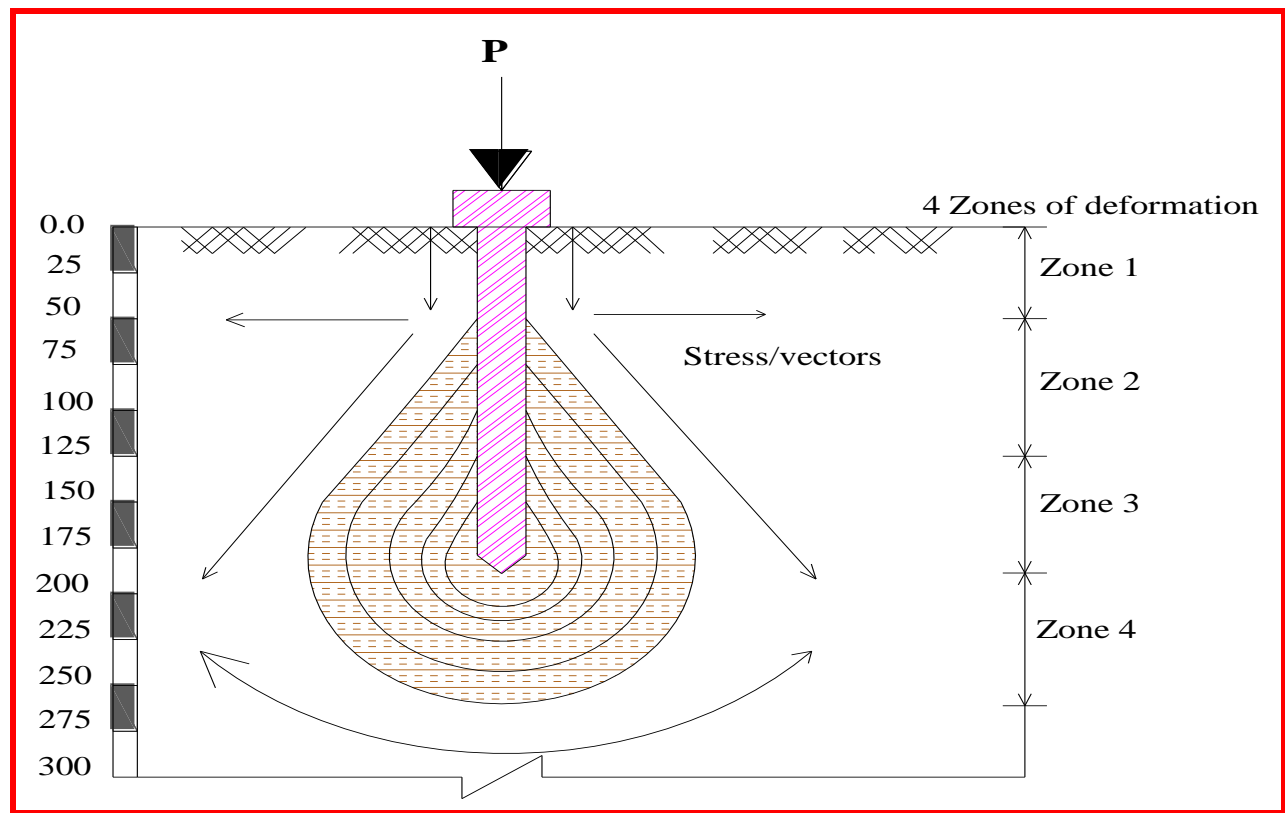

Fig. 7: Spatial movement and settlement of soils under axially loaded pile cap

IV.

\section{CONCLUSION}

The stress distribution pattern, intensity and magnitude in soil around tapered piles bored into compressive clay soil obtained from sites on the outskirt of Minsk region, when subjected to compressive axial loads investigated in this study have been presented. The results of the investigations showed that in compressive clay, the stress increases towards the center line of pile-pile cap joint of tapered piles irrespective of tapering angle only up to $0.5 \mathrm{~m}$ below the cap, (same as depth of pile cap itself), beyond this point, the magnitude and pattern of stress changes. The vertical normal stress under the pile cap increases from zero at the surface to $\mathbf{4 2 \%}$ in depth lower than $\mathbf{3 . 5 R}$, and $\mathbf{5 5 \%}$ beyond this point. The maximum principal stress is directed along the radius vector $\mathrm{R}$ and reduces radially outward from the pile centerline. The shear stress value beyond the radius vector, $\boldsymbol{R}$ is of $\mathbf{7 . 0 3} \mathrm{kPa}$ for the calculated/theoretical test, while a higher value $7.39 \mathrm{kPa}$ was obtained on the field. The average depth of failure zone for tapered piles with pile spacing $(\boldsymbol{\eta})$ of $\mathbf{0 . 9 5}$, and tapering angle (a) $\mathbf{0 . 9 5}^{\mathbf{0}}$ is $\mathbf{7 . 5}$ times pile diameter, whereas it's $\mathbf{1 0}$ times diameter of piles when the tapering angle is increased to $\mathbf{1 . 4 3}^{\mathbf{0}}$. Stress intensity, which is directly proportional to settlement, is also influenced by the tapering angle relative to the diameter of the pile, and this effect increases with incremental depth of pile penetration into compressive clay soil. Pile cap settlement is $\mathbf{5 - 1 0 \%}$ higher in tapered piles with lower tapering angle. While laboratory test revealed soils on the upper layer of tapered piles with higher tapering angle underwent greater stress, the field tests result shows the contrary. Slightly larger confining pressure for the laboratory test as well as induced stress on the field may be responsible for this.

\section{ACKNOWLEDGEMENTS}

The author is grateful I.L. Boiko and M. Alhassan for their contributions, JSC Syncline and GEOSERVICE Minsk, for the machinery and detailing, as well as other technical staff who assisted during the investigations.

\section{REFERENCES}

[1] R. Hooke and J. B. Hansen, Stress analysis, Strain analysis and Shearing of soils, in The Engineering of foundations, available at http://.mcgraw-hill.com/sites/dl/free/0072500581/373512/Ch04.pdf

[2] S. Manandhar and N. Yasufuku, Evaluation of skin friction of tapered piles in sands based on Cavity Expansion Theory, Memoirs of the Faculty of Engineering, Kyushu University, Vol. 71(4), 2011, 101126.

[3] J. E. Bowles, Foundation analysis and design 5th Edition, (Singapore: McGraw-Hill, 1997).

[4] J. Won, S.Y. Ahn, S. Jeong, J. Lee and S.Y. Jang, Nonlinear three-dimensional analysis of pile group supported columns considering pile cap flexibility, Computers and Geotechnics, (33), 2006, 355-370.

[5] B. M. Das and G. V. Ramana, Principles of soil dynamics $2^{\text {nd }}$ Edition, (Stamford CT Connecticut: Cenpage Learning, 2011).

[6] M. V. Boussinesq, Application des Potentiels â L'Etude de L'Équilibre et du Mouvement des Solides Élastiques, Gauthier-Villars, Paris, 1885. 
[7] M. J. Boussinesq, Application des potentiels a l'etude de l'equilibre et du movement des solides elastiques, principalement au calcul des deformations et des pressions que produisent, dans ces solides, des efforts quelconques exerces sur une petite partie de leur surface ou de leur interieur: Memoire suivi de notes etendues sur divers points de physique mathematique et d'analyse," GauthierVillars, Paris, 1885, pp. 722 .

[8] W. E. A. Acum and L. Fox, Computation of Load Stresses in a Three Layer Elastic System, Geotechnique, Vol. 2, 1951, 293-300.

[9] C. R Foster and S. M. Fergus, Stress Distribution in a Homogeneous Soil, Res. Report No. 12-F, Highway Research Board, 1951, 36 pp.

[10] H. Koning, Stress Distribution in a Homogeneous, Anisotropic, Elastic Semi-Infinite Solid, Proc., Fourth Intern. Conf. on Soil Mech. and Found. Engr., Vol. II, 1957, 335-338.

[11] E. S. Barber, Shear Loads on Pavements, Proceedings, International Conference on the Structural Design of Asphalt Pavements, Univ. of Michigan, 1963.

[12] M.A. Biot, Effect of Certain Discontinuities on the Pressure Distribution in a Loaded Soil, Physics, Vol. $6,1935,367-375$

[13] A. E. Cummings, Distribution of Stresses Under a Foundation, Transactions, ASCE, Vol. 101, 1936, $1072-1134$

[14] T. W. Adejumo, Settlement and Deformation Pattern of Modeled Wooden Piles in Clay, International Journal of Advanced Technology and Engineering Research, Vol.3 (3), 2013, 94-99.

[15] S. Manandhar, N. Yasufuku and K. Omine, Application of cavity expansion theory for evaluation of skin friction of tapered piles in sands, International Journal of Geo-Engineering, 4(3), 2012, 5-17.

[16] R. E. Olson, Advance Soil Mechanics: Stress Distribution, Unit 8, available at http://www.cyut.edu.tw/ jrlai/CE7332/Chap8.pdf

[17] L. Bjerrum, Progressive failure in Slopes of Over-consolidated Plastic Clays and Clay-shales, Proc. ASCE, 93(SM 5), 1967, 3-49.

[18] M. Alhassan, T. W. Adejumo and I. L. Boiko, Classification of Subsoil Bases in Nigeria. Electronic Journal of Geotechnical Engineering, 17 (J), 2012, 1407-1413.

[19] ГОСТ20276-99 Грунты. Методы полевого определения характеристик прочности и деформируемости: ГОСТ20276-99. - Введ. 13.07.2000. - Минск: Межгос. науч.-технич. комиссия по стандартизации, технич. нормированию и сертифика-ции в строительстве: НИИОСП им. Герсеванова, 2001. - 56 с.

[20] Г. К. Клейн, Расчет низких ростверков с учетом совместности их работы со сваями и основанием/ Г.К. Клейн, С.И. Родин// Научно-технический жур-нал. Основания, фундаменты и механика грунтов. - №4. 1977, С. 16-17.

[21] R. E. Ahlvin and H. H. Ulery, Tabulated Values for Determining the Complete Pattern of Stresses, Strains, and Deflections Beneath a Uniform Circular Load on a Homogeneous Half Space, Stress Distribution in Earth Masses, Highway Research Bulletin No. 342, 1962, 1-13.

[22] B. M. Das, Principles of geotechnical engineering $6^{\text {th }}$ Edition, (Canada: Thomson, 2006).

[23] K. Terzaghi, Theoretical Soil Mechanics, John Wiley and Sons, New York City, 1943, pp. 510.

[24] D. W. Taylor, Fundamentals of Soil Mechanics, John Wiley and Sons, New York, 1948, City, pp. 700.

[25] T. W ADEJUMO, M. ALHASSAN and I. L. BOIKO, Laboratory Investigation of Load Incremental Effect on the Deformation of Clay under Axially loaded Modeled Circular Piles, 11th International Conference "Modern Building Materials, Structures and Techniques", Vilnius Gediminas Technical University, Vilnius, Lithuania, Procedia Engineering, Elsevier Journals, Vol. 57, 2013, 83-87.

[26] T. W. ADEJUMO, Settlement Analysis of Wooden Piles in Clay, International Journal of Science, Engineering and Technology Research, Vol. 2(4), 2013, 778-782.

[27] H. G. Poulos, J. P. Carter and J. C. Small, Foundations and Retaining Structures-Research and Practice; State of the Art Lecture, Proc. 15th Int. Conf. Soil Mechs, Found. Eng., Istanbul, (4), 2002, 2527-2606.

[28] N. K. S. Al-Saoudi and H. M. Salim, The Behavior of groups of reinforced concrete model piles in expansive soil, Proc. of the 2nd International Conference on Unsaturated Soils, Beijing, Vol.1, 1998, 321-326.

[29] M. J. Tomlinson, Foundation design and construction 5th edition, (Upper Saddle River, NJ: Prentice Hall, 2001).

[30] R.Salgado, The engineering of foundations $1^{\text {st }}$ Edition, (New York: McGraw-Hill, 2008). 